\title{
Angiotensin I-converting-enzyme (ACE)- inhibitory activity of tryptic peptides of ovine $\beta$-lactoglobulin and of milk yoghurts obtained by using different starters
}

\author{
Jean-Marc CHOBERT*, Khaled El-ZAHAR**, Mahmoud SiTOHY**, \\ Michèle DalgalarRondo, François Métro, Yvan Choiset, \\ Thomas HAERTLÉ
}

Laboratoire d'Étude des Interactions des Molécules Alimentaires, INRA, rue de la Géraudière, BP 71627, 44316 Nantes Cedex 3, France

Received 27 September 2004 - Accepted 7 December 2004

Published online 25 February 2005

\begin{abstract}
The aim of this study was to investigate the angiotensin I-converting-enzyme (ACE)inhibitory activity of tryptic hydrolysates of ovine $\beta$-lactoglobulin, and of yoghurts made by using different starters. Ovine $\beta$-lactoglobulin (a mixture of variants A and B at a ratio of 50/50) was subjected to trypsin activity. The degree of hydrolysis of native whole $\beta$-lactoglobulin reached 56, 72, 93 and $95 \%$ after $1,2,8$ and $24 \mathrm{~h}$, respectively. ACE-inhibitory activity of tryptic hydrolysates increased with the time of hydrolysis, yielding 85,88 and $92 \%$ after 2, 12 and $24 \mathrm{~h}$, respectively. The determination of ACE-inhibitory activity of some tryptic peptides separated by RP-HPLC and identified by mass spectroscopy showed that the more hydrophilic peptides showed the higher activity. Yoghurts obtained by fermentation of ovine milk with four different sets of starters, and their fractions soluble or not at $\mathrm{pH} 4.6$ also showed an ACE-inhibitory activity. The maximum activity was obtained in the case of insoluble fractions at $\mathrm{pH} 4.6$ of yoghurts made with the set of starters YC-183.
\end{abstract}

ovine milk / tryptic peptide / yoghurt / ACE-inhibitory activity

Résumé - Activité inhibitrice de l'enzyme de conversion de l'angiotensine I (ECA) de peptides trypsiques de la $\beta$-lactoglobuline du lait de brebis et de yoghourts obtenus à partir de différents levains. Une activité inhibitrice de l'enzyme de conversion de l'angiotensine I (ECA) a été recherchée dans les peptides trypsiques de la $\beta$-lactoglobuline du lait de brebis et dans des fractions issues de yoghourts fabriqués à partir de différents ferments lactiques. La $\beta$-lactoglobuline ovine (un mélange des variants $\mathrm{A}$ et $\mathrm{B}$ ) a été soumise à une hydrolyse trypsique. Les degrés d'hydrolyse de la $\beta$-lactoglobuline ont atteint 56, 72, 93 et $95 \%$ respectivement après $1,2,8$ et 24 h d'hydrolyse. L'activité inhibitrice de l'ECA des hydrolysats trypsiques augmentait avec la durée de l'hydrolyse, atteignant 85,88 et $92 \%$ respectivement après 2,12 et $24 \mathrm{~h}$. La détermination de l'activité inhibitrice de l'ECA de quelques peptides trypsiques séparés par CLHP en phase inversée et identifiés par spectrométrie de masse a montré que les peptides les plus hydrophiles présentaient l'activité la plus

\footnotetext{
* Corresponding author: chobert@ nantes.inra.fr

** Permanent address: Zagazig University, Faculty of Agriculture, Biochemistry Department, Zagazig, Egypt
} 
grande. Des yoghourts fabriqués par fermentation du lait de brebis à l'aide de quatre compositions différentes de levains ainsi que leurs fractions solubles ou non à $\mathrm{pH}$ 4,6 présentaient aussi une activité inhibitrice de l'ECA. Le maximum d'activité a été obtenu avec les fractions insolubles à $\mathrm{pH}$ 4,6 de yoghourts fabriqués avec le levain YC-183.

\section{lait de brebis / peptide trypsique / yaourt / activité inhibitrice de l'ECA}

\section{INTRODUCTION}

$\beta$-Lactoglobulin (BLG) is the major whey protein in the milk of ruminants and of some (but not all) other mammalian genera. Proteolysis of whey proteins is one of the means of reducing their antigenicity $[49,50]$. BLG is one of the allergenic components of milk [15, 49], eliciting allergies in young infants. Proteolysis of whey proteins is also used in industry as a means of improving their functional properties (solubility, emulsifying and foaming properties) $[25,27]$ and flavor [7]. On the other hand, food proteins are potential sources of many biologically active peptides. These peptides, inactive within the sequence of parent protein, are activated once released during gastrointestinal digestion or during food processing $[21,31]$. Peptides with biological activity can be produced from milk proteins in two ways: (i) fermentation of milk using proteolytic starter cultures, and (ii) enzymatic hydrolysis with digestive enzymes. During the fermentation of milk with certain dairy starters, peptides with various biological activities can be formed [5, 48]. Biological activities include opioid agonist and antagonist peptides, hypotensive peptides which inhibit angiotensin I-converting enzyme (ACE), and mineral binding, immunomodulatory, antibacterial and antithrombotic peptides $[10,32]$.

ACE (peptidyldipeptide hydrolase, EC 3.4.15.1) has been associated with the rennin-angiotensin system, which converts angiotensin I into a potent vasoconstrictor; angiotensin II. ACE plays a major physiological role in the regulation of local levels of several endogenous bioactive peptides. ACE is an exopeptidase, which cleaves dipeptides from the $\mathrm{C}$-terminal of various peptide substrates. Inhibition of ACE can exert an anti-hypertensive effect as a consequence of the decrease in angiotensin II activity and the concomitant increase in bradykinin activity. It is postulated that the mechanism of ACE inhibition involves inhibitor interaction with an anionic binding site that is distinct from the catalytic site. It is expected that peptide conformation should contribute to ACE-inhibitory potency [17]. After the discovery of competitive ACE inhibitors in snake venom [16], several ACE-inhibitory peptides were identified by in vitro enzymatic digestion of milk proteins or chemical synthesis of peptide analogues [20]. ACE inhibitors derived from milk proteins represent different fragments of casein, named casokinins [32], or whey proteins, named lactokinins [17]. ACE inhibitory peptides have been isolated from the enzymatic digest of various food proteins and are, at present, the most actively studied bioactive peptide group [10, $17,38]$. The majority of casein-derived ACE-inhibitory peptides have moderate inhibitory potencies within an $\mathrm{IC}_{50}$ range of $100-500 \mu \mathrm{mol} \cdot \mathrm{L}^{-1}$ as compared with Captopril $\left(0.004 \mu \mathrm{mol} \cdot \mathrm{L}^{-1}\right)$. The best ACEinhibitory activity was obtained in the case

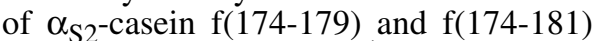
with an $\mathrm{IC}_{50}$ of $4 \mu \mathrm{mol} \cdot \mathrm{L}^{-1}$.

In dairy products, the type of lactic acid bacteria starter used is one of the main factors that influences the synthesis of hypotensive peptides. The release by microbial fermentation of various bioactive peptides from milk proteins has been reported in many studies. Pihlanto-Leppälä et al. [39] studied the potential formation of ACE-inhibitory peptides from cheese whey and caseins during fermentation, with various commercial lactic acid starters used in the manufacture of yoghurt, ropy milk and sour milk. Further digestion of the above-mentioned dairy foods with pepsin and trypsin resulted in an ACE inhibition rate varying between 35 and $61 \%$ by the whey protein hydrolysates and $86 \%$ by the casein hydrolysates, respectively. Two widely used industrial strains, $L a c$ tobacillus delbrueckii subsp. bulgaricus SS1 
and Lactococcus lactis subsp. cremoris FT4 can produce ACE-inhibitory peptides during milk fermentation [19].

Daily ingestion of foods containing peptides with potent ACE-inhibitory activities may be effective at keeping the human blood pressure low. The aim of this study was to detect an ACE-inhibitory activity in peptides obtained by hydrolysis with trypsin of ovine BLG and in yoghurts prepared from ovine milk by using different starters.

\section{MATERIALS AND METHODS}

\subsection{Preparation of ovine BLG}

Fresh ovine milk whey was prepared from skimmed milk (Lacaune breed, dairy farm of INRA, Rennes, France) by acid precipitation of caseins at $\mathrm{pH} 4.6$ with $1 \mathrm{~N} \mathrm{HCl}$. Caseins were removed by centrifugation at $10000 \mathrm{~g}$ for $30 \mathrm{~min}$ at $4{ }^{\circ} \mathrm{C}$. The supernatant containing whey proteins was dialyzed for $48 \mathrm{~h}$ against distilled water to eliminate lactose, then frozen and lyophilized.

BLG was isolated from fresh whey using anion-exchange chromatography on a DEAESepharose Fast Flow column $(300 \times 50 \mathrm{~mm}$; Amersham-Pharmacia, Orsay, France). This column was equilibrated with $25 \mathrm{mmol} \cdot \mathrm{L}^{-1}$ Tris, $\mathrm{pH} 8.0$, containing $5 \mathrm{mmol} \cdot \mathrm{L}^{-1} \mathrm{CaCl}_{2}$ and was eluted using linear $\mathrm{NaCl} 0-1 \mathrm{~mol} \cdot \mathrm{L}^{-1}$ gradient. BLG was further purified by gel permeation chromatography on a TSKG3000 SWXL column $(300 \times 7.8 \mathrm{~mm}$; Tosohaas, Montgomeryville, PA, USA). The elution was carried out at a flow rate of $0.8 \mathrm{~mL} \cdot \mathrm{min}^{-1}$ with $30 \mathrm{mmol} \cdot \mathrm{L}^{-1}$ sodium phosphate, pH 6.7 or with $30 \mathrm{mmol} \cdot \mathrm{L}^{-1}$ glycine, $\mathrm{pH}$ 2.5. Homogeneity of BLG was checked by SDS-tricine polyacrylamide gel electrophoresis (PAGE) according to the method of Schagger and von Jagow [42] and $\mathrm{C}_{18}$ reversed phase-high performance liquid chromatography (RP-HPLC) as previously described [13]. The BLG obtained was over $95 \%$ pure and was a mixture of variants $\mathrm{A}$ and $\mathrm{B}$ at a ratio 50/50.

\subsection{Tryptic hydrolysis}

BLG was dissolved in $0.2 \mathrm{~mol} \cdot \mathrm{L}^{-1}$ Tris$\mathrm{HCl}$ buffer, $\mathrm{pH}$ 8.0, to obtain a final protein concentration of $2 \mathrm{mg} \cdot \mathrm{mL}^{-1}$. TPCK-trypsin
(EC 3.4.21.4, type XIII from bovine pancreas; Sigma Chemical Company, St. Louis, $\mathrm{MO}$, USA) solubilized in $10 \mathrm{mmol} \cdot \mathrm{L}^{-1} \mathrm{HCl}$ at an initial concentration of $1 \mathrm{mg} \cdot \mathrm{mL}^{-1}$ was added to the reaction mixture to give a final enzyme/substrate $(E / S)$ ratio of $1 \%(w / w)$. Incubation was performed for $24 \mathrm{~h}$ at $37^{\circ} \mathrm{C}$. At intervals, the reaction was stopped by the addition of $1 \mathrm{~N} \mathrm{HCl}$ until $\mathrm{pH} 2.0$. All aliquots were then kept frozen at $-20{ }^{\circ} \mathrm{C}$ until analysis by RP-HPLC.

\subsection{Separation of tryptic peptides by RP-HPLC}

Chromatographies were carried out on a Waters 2695 separation module equipped with a Waters 996 photodiode array detector using the Millenium software (Waters, Millford, MA, USA). RP-HPLC was run on a Nucleosil $\mathrm{C}_{18}$ column $(250 \times 4 \mathrm{~mm}$; Macherey Nagel, Hoerdt, France), equilibrated with solvent A $(0.11 \%$, v/v, trifluoroacetic acid (TFA) in $\mathrm{H}_{2} \mathrm{O}$ ). Elution was performed by using a gradient from $10 \%$ solvent $\mathrm{B}\left(80 \%\right.$ acetonitrile, $19.91 \% \mathrm{H}_{2} \mathrm{O}$, $0.09 \%$ TFA, v/v/v) to $100 \%$ solvent $\mathrm{B}$ in $23 \mathrm{~min}$. The temperature of the column was maintained at $40{ }^{\circ} \mathrm{C}$ and the flow rate was $0.6 \mathrm{~mL} \cdot \mathrm{min}^{-1}$. The absorbance of the eluted fractions was recorded at $220 \mathrm{~nm}$.

\subsection{Nanoscale capillary liquid chromatography-tandem mass spectrometric (LC-MS/MS) analysis}

LC-MS/MS analysis of the digested ovine BLG was performed using an UltiMate capillary LC system (LC Packings, Dionex, Amsterdam, The Netherlands) coupled to a hybrid quadrupole orthogonal acceleration time-of-flight tandem mass spectrometer (Q-TOF Global, Micromass, Manchester, UK). The LC-MS union was made with a PicoTip (New Objective, Woburn, MA, USA) fitted on a Z spray (Micromass) interface. Chromatographic separations were performed on a reversed phase (RP) capillary column $\left(\mathrm{C}_{18}, 3 \mu \mathrm{m}, 100 \AA\right.$, $15 \mathrm{~cm}$ length, $75 \mu \mathrm{m}$ i.d., LC Packings) with a flow of $170 \mathrm{~nL} \cdot \mathrm{min}^{-1}$. The gradient profile used consisted of a linear gradient from $98 \%$ solvent 
$\mathrm{A}\left(\mathrm{H}_{2} \mathrm{O} /\right.$ acetonitrile/formic acid, 80/20/0.1, $\mathrm{v} / \mathrm{v} / \mathrm{v})$ to $60 \%$ solvent $\mathrm{B}\left(\mathrm{H}_{2} \mathrm{O} /\right.$ acetonitrile/ formic acid, 5/95/0.1, v/v/v) in $70 \mathrm{~min}$.

Mass data acquisitions were obtained by Mass Lynx Software (Micromass) using automatic switching between MS and MS/ MS modes. Peptides eluted from the chromatographic column were detected for $1 \mathrm{~s}$; when their signal reached a defined threshold (4 counts/s) they could be selected for fragmentation. A MS/MS scan (1 s) was then performed on the three most intense peptide ions detected. MS/MS scans of each selected ion were summed until the total fragmentation time attributed to one selected precursor had been reached or the signal in a MS/MS scan had fallen to 0. Acquisitions were performed with the dynamic exclusions of $m / z$ ratios of already fragmented ions (exclusion of a $\pm 0.3 \mathrm{~g} \cdot \mathrm{mol}^{-1}$ mass window around the $m / z$ ratio of previously selected precursors). Fragmentation was performed using argon as the collision gas and the collision energy profile was optimized. The software used for data acquisition was Mass Lynx 4.0 (Micromass) and the treatment of data was performed by using the Protein Lynx global server Version 2 (Micromass).

\subsection{Starter cultures}

Four sets of starters were obtained from Christian Hansen (Copenhagen, Denmark). One set of starters was ropy culture (YC191), which is a well-defined mixed strain culture containing Streptococcus thermophilus ST-143 and Lactobacillus delbrueckii subsp. bulgaricus (LB-18 and LB-CH2). The other set of starters (YC-460) was a standard yoghurt culture (non-ropy) containing mixed strain culture of Streptococcus thermophilus and Lactobacillus delbrueckii subsp. bulgaricus at a ratio of 1:1. Another starter was Yo-flex culture (YC-183), which is a mixed strain culture of Streptococcus thermophilus and Lactobacillus delbrueckii subsp. bulgaricus at a ratio of 1:1. The last starter was culture ABT-3, which is a well-defined mixed-strain culture containing Streptococcus thermophilus TH4, Lactobacillus acidophilus LA5 and Bifidobacterium bifidum $\mathrm{Bb} 12$ at a ratio of 1:1:1.

\subsection{Preparation of yoghurts}

Yoghurts were prepared according to the methods described by Irvine [24] and Anifantakis [2] as previously described [11, 12]. Raw ewe's milk was pasteurized at different temperatures and for different times $\left(63{ }^{\circ} \mathrm{C}\right.$ for $30 \mathrm{~min} ; 73^{\circ} \mathrm{C}$ for $15 \mathrm{~min} ; 85^{\circ} \mathrm{C}$ for $10 \mathrm{~min}$ or $96^{\circ} \mathrm{C}$ for $5 \mathrm{~min}$ ), then cooled to $42{ }^{\circ} \mathrm{C}$. The milk was inoculated at $42{ }^{\circ} \mathrm{C}$ with $0.5 \%$ of the cultures YC-191, YC-460, YC-183 or ABT-3, formerly reactivated for $4 \mathrm{~h}$. The fermentation of the yoghurt was considered to be achieved when the $\mathrm{pH}$ value reached 4.6. Yoghurt was stored at $-20{ }^{\circ} \mathrm{C}$ until analysis.

\subsection{ACE-inhibitory activity}

ACE inhibition ( $n=3$ for each sample) was assayed by using the method of Cushman and Cheung [8] as modified by Kim and Chung [26]. Briefly, $80 \mu \mathrm{L}$ of each sample (trypsin hydrolysate, tryptic peptide fractions, and yoghurts after complete fermentation) were added to $200 \mu \mathrm{L}$ of $0.1 \mathrm{~mol} \cdot \mathrm{L}^{-1}$ potassium phosphate containing $0.3 \mathrm{~mol} \cdot \mathrm{L}^{-1} \mathrm{NaCl}$, and $5 \mathrm{mmol} \cdot \mathrm{L}^{-1}$ hippurylhistidyl-leucine (Hip-His-Leu; Sigma), $\mathrm{pH}$ 8.3. Twenty microliters of ACE (EC 3.4.15.1; 5.1 $\mathrm{U} \mathrm{mg}^{-1}$; Sigma) were added and the reaction mixture was incubated at $37^{\circ} \mathrm{C}$ for $30 \mathrm{~min}$. The reaction was stopped by adding $250 \mu \mathrm{L}$ of $1 \mathrm{~N} \mathrm{HCl}$. The liberated hippuric acid was extracted with ethyl acetate, heat evaporated at $95{ }^{\circ} \mathrm{C}$ for $10 \mathrm{~min}$, dissolved in distilled water and the absorbance of the extract was determined at $228 \mathrm{~nm}$ to evaluate the ACE-inhibitory activity. The inhibition activity was calculated using the following equation:

$$
\begin{aligned}
& \text { Inhibition activity }(\%)= \\
& \qquad 100 \times[(\mathrm{A}-\mathrm{B})-(\mathrm{C}-\mathrm{D})] /(\mathrm{A}-\mathrm{B})
\end{aligned}
$$

where $\mathrm{A}$ is the absorbance of the solution containing ACE, but without the sample, B is the absorbance of a solution with ACE previously inactivated by adding $\mathrm{HCl}$ and without the sample, $\mathrm{C}$ is the absorbance in the presence of ACE and sample, and D is the absorbance with ACE previously inactivated with $\mathrm{HCl}$ and containing the sample. The inhibitory activity of the hydrolysates 

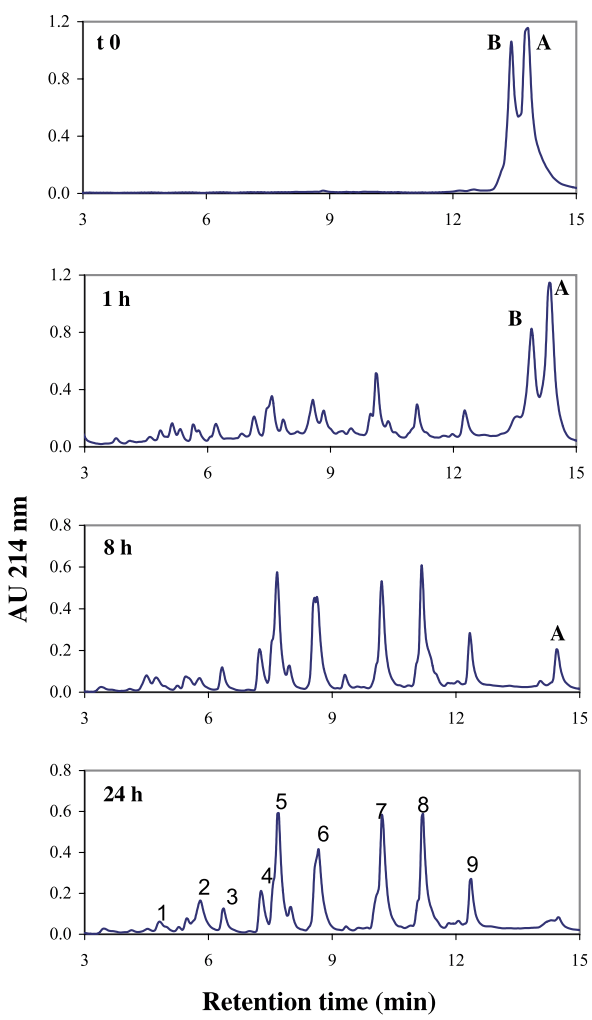

Figure 1. RP-HPLC on Nucleosil $\mathrm{C}_{18}$ column $(250 \times 4 \mathrm{~mm})$ equilibrated with solvent $\mathrm{A}$ $(0.11 \%$ TFA) of $\beta$-lactoglobulin (variants A and B) and of its tryptic peptides obtained after 1,8 and $24 \mathrm{~h}$ of hydrolysis. Elution was performed by using a gradient from $10 \%$ solvent $\mathrm{B}(80 \%$ acetonitrile, $19.91 \% \mathrm{H}_{2} \mathrm{O}, 0.09 \%$ TFA) to $100 \%$ solvent $\mathrm{B}$ in $23 \mathrm{~min}$ at a flow-rate of $0.6 \mathrm{~mL} \cdot \mathrm{min}^{-1}$. Peak numbers $1-9$ are those indicated in Table I.

or collected fractions was expressed as percentage of ACE inhibition at a given protein concentration $\left(0.2 \mathrm{mg} \cdot \mathrm{mL}^{-1}\right.$ in the case of peptides eluted in peaks $1-3 ; 0.3 \mathrm{mg} \cdot \mathrm{mL}^{-1}$ in the case of peptides eluted in the peaks 4 and $5 ; 0.55 \mathrm{mg} \cdot \mathrm{mL}^{-1}$ in the case of peptides eluted in the peaks $6-8$ and $0.9 \mathrm{mg} \cdot \mathrm{mL}^{-1}$ in the case of peptide eluted in peak 9; see Fig. 1 and Tab. I). Due to some limitation of the OPA method for determining the peptide concentration, and to the presence of more than one peptide in each fraction, $\mathrm{IC}_{50}$ (the concentration of an ACE inhibitor needed to inhibit $50 \%$ of ACE activity) was not used.

\section{RESULTS AND DISCUSSION}

\subsection{Tryptic hydrolysis of BLG}

Native ovine BLG was gradually degraded by trypsin at $\mathrm{pH} 8$ and $37{ }^{\circ} \mathrm{C}$. The hydrolysis rate (based on the relative peak area corresponding to the whole BLG) was $56,72,93$ and $95 \%$ after $1,2,8$ and $24 \mathrm{~h}$, respectively (data not shown). BLG variant $\mathrm{B}$ was more rapidly hydrolyzed by trypsin than BLG variant A, yielding about 70 and $44 \%$ hydrolysis, respectively, after $1 \mathrm{~h}$ of incubation. Nearly complete hydrolysis $(95 \%)$ was obtained for the two variants after $24 \mathrm{~h}$. Higher susceptibility of variant B to proteolysis was previously observed with pepsin [14]. The difference in susceptibility to trypsin hydrolysis reported here for the ovine BLG variants was also observed previously in the case of the variants of bovine BLG [23, 37, 50] and was attributed to structural differences between them. The absence of an arginyl residue in position 148 of ovine BLG A may explain the different yield of hydrolysis between the two variants.

\subsection{Mass characterization of BLG tryptic peptides}

Data presented in Table I show the ovine BLG tryptic components of the RP-HPLC fractions corresponding to the peaks numbered 1 to 9 (Fig. 1). Peaks 1 and 2, which are separated in the retention time range 3 6 min, contain 6 peptides (G9-K14; I71K75; I71-K77; I84-K91; T125-K135, and A139-K141) with low molecular masses (331-1244 $\left.\mathrm{g} \cdot \mathrm{mol}^{-1}\right)$ and of hydrophilic nature. The hydrophilicity is determined by both the nature of the amino acid residues composing the peptides as well as by the size of the peptide. The longest peptide in this group $\left(1243.5 \mathrm{~g} \cdot \mathrm{mol}^{-1}\right)$ has 11 amino acid residues, 4 of which bear negative (3 Glu and 1 Asp) and one a positive charge (Lys) in addition to terminal charges. The size of the other peptides ranged between 3 and 8 amino acids. It can also be observed 
Table I. Amino acid composition, molecular mass and ACE-inhibitory activity of $\beta$-lactoglobulin tryptic peptides after $24 \mathrm{~h}$ hydrolysis.

\begin{tabular}{|c|c|c|c|c|}
\hline Peak number* & Position & $\begin{array}{c}\text { Molecular } \\
\text { mass }\end{array}$ & Sequences of amino acids & $\begin{array}{c}\text { ACE inhibition } \\
(\%)\end{array}$ \\
\hline \multirow[t]{4}{*}{$1(4.8 \mathrm{~min})$} & $139-141$ & 331.4 & ALK & \multirow{4}{*}{$67.6 \pm 0.8$} \\
\hline & $71-75$ & 573.7 & IIAEK & \\
\hline & $71-77$ & 802.7 & IIAEKTK & \\
\hline & $84-91$ & 915.8 & IDALNENK & \\
\hline \multirow[t]{3}{*}{$2(5.8 \mathrm{~min})$} & $9-14$ & 672.7 & GLDIQK & \multirow{3}{*}{$71.2 \pm 1.3$} \\
\hline & $84-91$ & 915.7 & IDALNENK & \\
\hline & $125-135$ & 1243.5 & TPEVDNEALEK & \\
\hline $3(6.4 \mathrm{~min})$ & $1-8$ & 932.6 & IIVTQTMK & $70.8 \pm 1.2$ \\
\hline $4(7.3 \mathrm{~min})$ & $142-148$ & 836.5 & ALPMHIR & $62.6 \pm 0.6$ \\
\hline \multirow[t]{5}{*}{$5(7.7 \mathrm{~min})$} & $78-83$ & 673.7 & IPAVFK & \multirow{5}{*}{$56.4 \pm 0.7$} \\
\hline & 15-20 (variant A) & 695.7 & VAGTWY & \\
\hline & $92-100$ & 1064.4 & VLVLDTDYK & \\
\hline & $92-101$ & 1192.6 & VLVLDTDYKK & \\
\hline & $125-138$ & 1633.5 & TPEVDNEALEKFDK & \\
\hline \multirow[t]{2}{*}{$6(8.6 \mathrm{~min})$} & $61-69$ (S-S) 149-162 & 2618.1 & WENGECAEK (S-S) LAFNPTQLNGECHV & \multirow{2}{*}{$56.5 \pm 0.8$} \\
\hline & $61-70(S-S)$ 149-162 & 2748.3 & WENGECAEKK (S-S) LAFNPTQLNGECHV & \\
\hline \multirow[t]{2}{*}{$7(10.2 \mathrm{~min})$} & $21-40$ & 2030.3 & SLAMAASDISLLDAQSAPLR & \multirow{2}{*}{$50.7 \pm 0.8$} \\
\hline & $41-60$ & 2311.4 & VYVEELKPTPEGNLEILLQK & \\
\hline \multirow[t]{2}{*}{$8(11.2 \mathrm{~min})$} & $102-124$ & 2648.1 & YLLFCMENSAEPEQSLACQCLVR & \multirow{2}{*}{$43.6 \pm 0.3$} \\
\hline & $15-40$ (variant B) & 2680.4 & VAGTWHSLAMAASDISLLDAQSAPLR & \\
\hline $9(12.3 \mathrm{~min})$ & $15-40$ (variant $\mathrm{A})$ & 2708.7 & VAGTWYSLAMAASDISLLDAQSAPLR & $30.0 \pm 0.4$ \\
\hline
\end{tabular}

* Peak numbers are those indicated in RP-HPLC separation of tryptic peptides.

that the long peptide T125-K135 was derived from a region close to the terminal carboxylic end. The peptide population of retention times 6.4-7.7 min appearing under peaks $3-5$ included peptides of molecular masses between 674 and $1634 \mathrm{~g} \cdot \mathrm{mol}^{-1}$ : I1-K8; V15-Y20, which is the result of an atypical cleavage Tyr20-Ser21; I78-K83; V92-K100; V92-K101; T125-K138 and A142-R148. The largest peptides of 23 and 24 amino acid residues $\left(2618\right.$ and $\left.2748 \mathrm{~g} \cdot \mathrm{mol}^{-1}\right)$ obtained in peak 6 are actually composed of two peptides (W61-K69 and W61-K70) bound by
C64-C160 to peptide L149-V162. The last peptide population resolved in peaks 7,8 and 9 (V15-R40; S21-R40; V41-K60 and Y102-R124 of retention times $10-12 \mathrm{~min}$ ) is characterized by high molecular masses (2030-2709 $\left.\mathrm{g} \cdot \mathrm{mol}^{-1}\right)$. Most of these peptides were derived from the $\mathrm{N}$-terminal region; two different peptides V15-R40 differed in position 20, corresponding to the two variants of BLG. Since these hydrophobic peptides were the first peptides appearing at the early stages of tryptic hydrolysis, it can be concluded that the tryptic action starts at the 
$\mathrm{N}$-terminal part of the BLG molecule. Of course, this observation confirms general features of higher accessibilities and susceptibilities of protein $\mathrm{N}$ termini to proteolytic attack and to protein-protein interactions in general.

\subsection{ACE-inhibitory activity in tryptic hydrolysates of BLG}

ACE-inhibitory activity increased with the time of trypsin hydrolysis of BLG (85, 88 and $92 \%$ activity after 2,12 and 24 h of hydrolysis, data not shown), which remains in agreement with data presented in the literature showing that ACE-inhibitory activity increases with decreasing size of the peptides. The data in Table I shows the ACE-inhibitory activity of peptides eluted in peaks $1-9$ by RP-HPLC of tryptic hydrolysate. The highest activity was observed in the peaks 1-4 containing hydrophilic peptides of low molecular masses. Some of the tryptic peptides of ovine BLG showing an ACE-inhibitory activity have been obtained in the case of bovine milk by using different proteases: $f(9-14), f(15-20)$ which corresponds to an atypical site of cleavage Tyr20Ser21, f(142-148); some others have not yet been described in the case of bovine milk: $\mathrm{f}(1-8), \mathrm{f}(61-69 / 70$ - S-S - 149-162) and other non-purified tryptic peptides eluted in peak 1 .

ACE is widely distributed in mammalian tissues. It is present in plasma, lung, kidney, heart, skeletal muscle, pancreas, spleen, placenta, arteries, testes, uterus and brain. It is also present as a brush border membranebound enzyme on epithelial cells of human jejunum. Therefore, many sites for the action of ACE-inhibitory peptides exist. Although there are several reports about the antihypertensive effects of casein-derived hydrolysates/peptides in rat and human nutrition studies [17], no reports to date appear to exist on the physiological effects of whey protein-derived ACE-inhibitory hydrolysates/ peptides. Whey protein-derived ACE-inhibitory activities are not as potent as synthetic antihypertensive drugs such as Captopril $\left(\mathrm{IC}_{50}\right.$ of $\left.0.004 \mu \mathrm{mol} \cdot \mathrm{L}^{-1}\right)$. Parallel experiments with casein-derived ACE-inhibitory hydrolysates/peptides would indicate that the whey protein-derived ACE inhibition is sufficiently potent to exert an efficient antihypertensive effect [47].

The importance of specific amino acid sequences in ACE-inhibitory activity has been suggested. The C-terminal part of the amino acid sequence of a peptide plays an important role in binding to ACE. Peptides that contain a hydrophobic amino acid at the initial three C-terminal positions are potent ACE inhibitors. The most efficient C-terminal amino acids are aromatic amino acids such as tryptophan, tyrosine and phenylalanine, as well as the imino amino acid, proline; the least favorable are the dicarboxylic amino acids [6]. Both amino acid residues in the C-terminal position and the amino acid sequence might be important in respect to ACE inhibition. The structure/activity data reported by Meisel [31] suggest that positive charge, such as on the guanidine group of the C-terminal arginine side chain, contributes substantially to the ACE-inhibitory activity of several peptides. PihlantoLeppälä et al. [39] suggested that the C-terminal lysine of BLG (f( 9-14) tryptic peptide) may contribute to the inhibitory activity of this peptide. In the present study, the ovine counterpart of this peptide was eluted in peak 2, which shows the highest ACE inhibition. The $\alpha$-lactalbumin (ALA), f(105-110) peptic peptide and BLG $\mathrm{f}(15-20)$ peptic peptide contain hydrophobic amino acid (leucine) at their C-terminus; in the case of BLG $\mathrm{f}(15-20)$ the penultimate amino acid is also hydrophobic. Leucine is present as the $\mathrm{C}$-terminal amino acid in $\beta$-lactorphin and $\alpha$-lactorphin, which have been shown to have potent ACE-inhibitory activity [34].

The ACE-inhibitory activity of bovine BLG hydrolysates is a result of various peptides liberated from different regions of the BLG chain. Trypsin, e.g., releases several peptides with moderate activity, namely BLG f(22-25), $\mathrm{f}(32-40), \mathrm{f}(81-83)$ and (142148) $[35,40,41]$. It should be observed that peptides $f(22-25), f(32-40)$, and $f(81-83)$ correspond to atypical tryptic cleavages. Several peptides have been isolated from whey protein digested with proteinase $\mathrm{K}$ of Tritirachium album; among them is a peptide corresponding to BLG f(78-80) ( $\beta$-lactosin), which showed the highest ACE-inhibitory 
activity [1]. BLG f(102-105), named lactorphin, obtained by the action of pepsin and trypsin, showed an ACE-inhibitory activity and is an opioid agonist $[3,34]$. This peptide was also obtained from whey by the action of proteases from Kluyveromyces marxianus var. marxianus [4]. Synthetic peptides $\mathrm{f}(102-103)$ and $\mathrm{f}(102-105)$ displayed an ACE-inhibitory activity [34]. There is evidence that the two catalytic sites of ACE may differ in several properties and may have different conformational requirements so that ACE inhibitors may inhibit only one of them. It is claimed that the mechanism of ACE inhibition also involves interaction with sub-sites normally unoccupied by substrates or with an anionic inhibitor-binding site different from the catalytic sites of the enzyme.

\subsection{ACE-inhibitory activity in yoghurts made with ovine milk}

The evolution of caseins and whey proteins in ovine milk submitted to different thermal treatments $\left(63{ }^{\circ} \mathrm{C} / 30 \mathrm{~min} ; 73{ }^{\circ} \mathrm{C} / 15 \mathrm{~min}\right.$; $85^{\circ} \mathrm{C} / 10 \mathrm{~min}$ or $96^{\circ} \mathrm{C} / 5 \mathrm{~min}$ ), before fermentation of yoghurts using four different sets of starters (YC-191, YC-460, YC-183 and ABT-3), has been previously described $[11,12]$. During the fermentation of yoghurts made with the different starters, ALA was hydrolyzed to a slightly greater extent than BLG. During fermentation of the yoghurts $\beta$-casein was slightly more degraded than $\alpha_{S}$-caseins, independent of the starter used. Generally, a more intense heat pre-treatment led to higher degradation of whey proteins and caseins during fermentation. Differences in proteolytic activity between the starters used (proteins more degraded by ABT-3 than by YC-183; whey proteins more degraded by YC-191; caseins more degraded by YC-460) may lead to an improvement in production and formulation of yoghurts differing in their physico-chemical and rheological properties. These differences in proteolytic activity may also have an incidence on the ACE-inhibitory activity of yoghurts and of their fractions.

ACE-inhibitory activity was measured at the end of fermentation of the yoghurts and on their fractions, soluble or insoluble at $\mathrm{pH}$ 4.6. The data in Table II shows that ACE-inhibitory activity of yoghurts and of their fractions soluble at $\mathrm{pH} 4.6$ increased with the temperature of pre-heating of the milk used in the fabrication of the yoghurts, until a maximum obtained in the case of the yoghurts made with ovine milk submitted to a pre-heating at $73{ }^{\circ} \mathrm{C} / 15 \mathrm{~min}$ or $85^{\circ} \mathrm{C}$ for $10 \mathrm{~min}$, independent of the set of starters used. The maximum of ACE-inhibitory activity was obtained in the case of the fractions insoluble at $\mathrm{pH} 4.6$ and particularly when yoghurts were made with the set of starters YC-183, independent of the heat pre-treatment of the milk.

ACE-inhibitory activity after fermentation of ovine milk was higher than that obtained after tryptic hydrolysis of ovine BLG, showing a more efficient cleavage for the formation of ACE-inhibitory peptides with the enzymes of bacterial origin. However, it was surprising that the maximum of ACE-inhibitory activity was obtained in the fraction insoluble at $\mathrm{pH} 4.6$ since it contains mainly unhydrolyzed caseins together with hydrophobic peptides and other peptides carried along during precipitation. In contrast, peptides contained in the fraction soluble at $\mathrm{pH} 4.6$ showed a poor ACE-inhibitory activity. Such a segregation between a soluble fraction rich in peptides with a C-term end hardly compatible with an inhibition of ECA and an insoluble fraction containing few peptides but with a C-term end leading to a great inhibition leads us to suppose that a "non-specific" inhibition might occur in the case of the fraction insoluble at $\mathrm{pH}$ 4.6.

ACE-inhibitory peptides, particularly those present in fermented milk, may act as hypotensive components. Such peptides, containing up to ten amino acids, may be released from milk proteins through the proteolytic activity of lactic acid bacteria. Casokinin sequences have been found in all casein fractions, but $\alpha_{\mathrm{S}_{1}-}$ and $\beta$-caseins, in particular, are rich in ACE-inhibitory sequences. Maruyama and Suzuki [28] showed that a tryptic hydrolysate of caseins contains ACE inhibitors. The active peptide inhibitors were purified and identified as $\alpha_{\mathrm{S}_{1} \text {-casein }}$ $\mathrm{f}(13-34)$. Later it was found that the peptides 
Table II. ACE-inhibitory activity of yoghurts prepared from ovine milk pre-treated at different temperatures by using different starter cultures.

\begin{tabular}{|c|c|c|c|c|}
\hline \multicolumn{5}{|c|}{ Whole yoghurt } \\
\hline cultures & $63{ }^{\circ} \mathrm{C} / 30 \mathrm{~min}$ & $73^{\circ} \mathrm{C} / 15 \min$ & $85^{\circ} \mathrm{C} / 10 \mathrm{~min}$ & $96{ }^{\circ} \mathrm{C} / 5 \mathrm{~min}$ \\
\hline YC-191 & $54.8 \pm 0.6$ & $65.7 \pm 0.7$ & $60.7 \pm 0.5$ & $48.8 \pm 0.4$ \\
\hline YC-460 & $62.1 \pm 0.8$ & $75.0 \pm 0.8$ & $76.2 \pm 0.8$ & $55.5 \pm 0.5$ \\
\hline YC-183 & $74.5 \pm 0.8$ & $76.2 \pm 0.8$ & $71.5 \pm 0.8$ & $63.6 \pm 0.8$ \\
\hline ABT-3 & $54.7 \pm 0.6$ & $66.6 \pm 0.7$ & $71.9 \pm 0.8$ & $59.1 \pm 0.7$ \\
\hline \multicolumn{5}{|c|}{$\begin{array}{c}\text { Fractions soluble } \\
\text { at } \mathrm{pH} 4.6\end{array}$} \\
\hline cultures & $63^{\circ} \mathrm{C} / 30 \mathrm{~min}$ & $73^{\circ} \mathrm{C} / 15 \mathrm{~min}$ & $85^{\circ} \mathrm{C} / 10 \mathrm{~min}$ & $96{ }^{\circ} \mathrm{C} / 5 \mathrm{~min}$ \\
\hline$\overline{\text { YC-191 }}$ & $31.3 \pm 0.3$ & $38.9 \pm 0.4$ & $42.4 \pm 0.4$ & $37.6 \pm 0.4$ \\
\hline YC-460 & $24.1 \pm 0.2$ & $38.9 \pm 0.4$ & $30.4 \pm 0.3$ & $22.6 \pm 0.2$ \\
\hline YC-183 & $33.5 \pm 0.4$ & $35.7 \pm 0.3$ & $29.3 \pm 0.3$ & $22.6 \pm 0.2$ \\
\hline ABT-3 & $23.9 \pm 0.3$ & $31.2 \pm 0.3$ & $36.2 \pm 0.4$ & $25.2 \pm 0.3$ \\
\hline \multicolumn{5}{|c|}{$\begin{array}{c}\text { Fractions insoluble } \\
\text { at } \mathrm{pH} 4.6\end{array}$} \\
\hline cultures & $63^{\circ} \mathrm{C} / 30 \mathrm{~min}$ & $73^{\circ} \mathrm{C} / 15 \mathrm{~min}$ & $85^{\circ} \mathrm{C} / 10 \mathrm{~min}$ & $96^{\circ} \mathrm{C} / 5 \mathrm{~min}$ \\
\hline YC-191 & $75.2 \pm 0.6$ & $93.1 \pm 0.8$ & $94.3 \pm 0.9$ & $96.9 \pm 0.8$ \\
\hline YC-460 & $92.1 \pm 0.8$ & $98.2 \pm 0.8$ & $100 \pm 0.9$ & $100 \pm 0.9$ \\
\hline YC-183 & $100 \pm 0.5$ & $100 \pm 0.7$ & $100 \pm 0.6$ & $100 \pm 0.9$ \\
\hline ABT-3 & $81.8 \pm 0.8$ & $87.5 \pm 0.7$ & $91.8 \pm 0.8$ & $92.5 \pm 0.7$ \\
\hline
\end{tabular}

corresponding to $\beta$-casein $\mathrm{f}(177-183), \alpha_{\mathrm{S} 1^{-}}$ casein $\mathrm{f}(23-27)$ and $\alpha_{\mathrm{S} 1}$-casein $\mathrm{f}(194-199)$ had ACE-inhibitory activity [29, 30].

In addition to tryptic hydrolysis, lactic acid fermentation also produces casokinins. Yamamoto et al. [51] showed that peptides produced by Lactobacillus proteases had ACE-inhibitory activity. The antihypertensive effect of a Japanese commercial fermented milk has been demonstrated both in spontaneously hypertensive rats (SHR) and in mildly hypertensive humans [43]. This product contains two ACE-inhibitory tripeptides, Val-Pro-Pro and Ile-Pro-Pro, which are formed from $\beta$-casein and $\kappa$-casein by fermentation of milk with Lactobacillus helveticus and Saccharomyces cerevisiae [36]. The antihypertensive effect in vivo of milk-derived peptides has been supported by recent studies of Sipola et al. [45, 46]. A long-term (up to 12 weeks) intake of a $L b$. helveticus fermented milk containing the tripeptides Val-Pro-Pro and Ile-Pro-Pro attenuated significantly the development of hypertension in young SHR, whereas skimmed milk intake did not affect the blood pressure. The effect was detectable after 6 weeks of treatment. Futhermore, Seppo et al. [43, 44] demonstrated that a daily ingestion of $150 \mathrm{~mL}$ of this fermented milk for 8 weeks decreased the blood pressure in slightly hypertensive human subjects. The effect of two fermented milks started by two $L b$. helveticus strains was also shown on in vivo ACE activity of normotensive rats [18]. Selected Lb. delbrueckii subsp. bulgaricus and Lactococcus lactis subsp. cremoris were used to produce two fermented milks that contained ACE-inhibitory peptides issuing from casein [19]. All the casein 
fragments had a high proportion of hydrophobic residues $(>60 \%)$. Sodium caseinates prepared from bovine, sheep, goat, pig, buffalo or human milk were hydrolyzed by a partially purified proteinase of $L b$. helveticus PR4 [33]. A fraction of sheep sodium caseinate hydrolysate with an ACE-inhibitory activity contained a mixture of peptides corresponding to $\alpha_{S_{1} \text {-casein }} \mathrm{f}(1-4), \mathrm{f}(1-6)$ and $\mathrm{f}(4-8)$ [33]. Higher activity was observed in the case of caprine and ovine BLG hydrolysates obtained with microbial enzymes than in those prepared with digestive enzymes, suggesting a more efficient cleavage for the formation of ACE-inhibitory peptides with the enzymes of bacterial origin [22]. Hydrolysates obtained with microbial enzymes contained BLG fragments of lower molecular masses than those obtained with the digestive enzymes. It is known that not only the $\mathrm{C}$-terminal residues are important for ACE-inhibitory activity, but also peptide size is determinant [22].

ACE-inhibitory peptides are believed to be competitive substrates for ACE. Though the structure-activity relationship of ACEinhibitory peptides has not been completely established, it appears to be strongly influenced by the C-terminal tripeptide sequence of the substrate [31].

Whey protein/hydrolysates may find application as nutraceuticals in various "physiologically functional foods". Nutraceuticals has been defined as any substance that is a food or part of a food providing medical and health benefits, including the prevention and treatment of disease [9].

\section{REFERENCES}

[1] Abubakar A., Saito T., Kitazawa H., Kawai Y., Itoh T., Structural analysis of new antihypertensive peptides derived from cheese whey protein by proteinase $\mathrm{K}$ digestion, $\mathrm{J}$. Dairy Sci. 81 (1998) 3131-3138.

[2] Anifantakis E.M., Proc. XXIII International Dairy Congress, 1990, vol. 1, pp. 420-432.

[3] Antila P., Paakkari I., Järvinen A., Mattila M.J., Laukkanen M., Pihlanto-Leppälä A., Mäntsälä P., Hellman J., Opioid peptides derived from in vitro proteolysis of bovine whey proteins, Int. Dairy J. 1 (1991) 215-229.
[4] Belem M.A.F., Gibbs B.F., Lee B.H., Proposing sequences for peptides derived from whey fermentation with potential bioactive sites, J. Dairy Sci. 82 (1999) 486-493.

[5] Clare D.A., Swaisgood H.E., Bioactive milk peptides: a prospectus, J. Dairy Sci. 83 (2000) 1187-1195.

[6] Cheung H.S., Wang F.L., Ondetti M.A., Sabo E.F., Cushman D.W., Binding of peptide substrates and inhibitors of angiotensinconverting enzyme. Importance of the COOH-terminal dipeptide sequence, J. Biol. Chem. 255 (1980) 401-407.

[7] Crossmann T.L., Use of whey-derived products as cheese flavoring agents or enhancers, 1985, US Patent 4.500.549.

[8] Cushman D.W., Cheung H.S., Spectrophotometric assay and properties of the angiotensin-I-converting enzyme of rabbit lung, Biochem. Pharmacol. 20 (1971) 1637-1648.

[9] De Felice S.L., The nutraceutical revolution; its impact on food industry research and development, Trends Food Sci. Technol. 6 (1995) 59-61.

[10] Dzuiba J., Minkiewicz P., Nalecz D., Iwaniak A., Database of biologically active peptide sequences, Nahrung 43 (1999) 190-195.

[11] El-Zahar K., Chobert J.-M., Sitohy M., Dalgalarrondo M., Haertlé T., Proteolytic degradation of ewe milk proteins during fermentation of yoghurts and storage, Nahrung 47 (2003) 199-206.

[12] El-Zahar K., Chobert J.-M., Dalgalarrondo M., Sitohy M., Haertlé T., Proteolysis of ewe's caseins and whey proteins during fermentation of yogurt and storage. Effect of the starters used, J. Food Biochem. 28 (2004) 319-335.

[13] El-Zahar K., Sitohy M., Dalgalarrondo M., Choiset Y., Métro F.. Haertlé T., Chobert J.-M., Purification and physico-chemical characterization of ovine $\beta$-lactoglobulin and $\alpha$-lactalbumin, Nahrung 48 (2004) 177-183.

[14] El-Zahar K., Sitohy M., Choiset Y., Métro F., Haertlé T., Chobert J.-M., Peptic hydrolysis of ovine $\beta$-lactoglobulin and $\alpha$-lactalbumin. Exceptional susceptibility of native ovine $\beta$-lactoglobulin to pepsinolysis, Int. Dairy J. 15 (2005) 17-27.

[15] Ena J.M., van Beresteijn E.C.H., Robben A.J.P.M., Schmidt D.G., Whey protein antigenicity reduction by fungal proteinases and a pepsin/pancreatic combination, J. Food Sci. 60 (1995) 104-116.

[16] Ferreira S.H., Bartet D.C., Greene L.J., Isolation of bradykinin-potentiating peptides from Bothrops jararaca venom, Biochemistry 9 (1970) 2583-2593.

[17] Fitzgerald R.J., Meisel H., Milk proteinderived peptide inhibitors of angiotensin 
I-converting enzyme, Br. J. Nutr. 84 (2000) S33-S37.

[18] Fuglsang A., Rattray F.P., Nilsson D., Nyborg N.C.B., Lactic acid bacteria: inhibition of angiotensin converting enzyme in vitro and in vivo, Antonie van Leeuwenhoek 87 (2003) 27-34.

[19] Gobetti M., Ferranti P., Smacchi E., Goffredi F., Addeo F., Production of angiotensin-I converting enzyme (ACE)-inhibitory peptides in fermented milks started by Lactobacillus delbrueckii subsp. bulgaricus SS14 and Lactococcus lactis subsp. cremoris FT4, Appl. Environ. Microbiol. 66 (2000) 38983904.

[20] Gobetti M., Stepaniak L., De Angelis M., Corsetti A., Di Cagno R., Latent bioactive peptides in milk proteins: proteolytic activation and significance in dairy processing, Crit. Rev. Food Sci. Nutr. 42 (2002) 223239.

[21] Gobetti M., Minervini F., Grizzello C., Angiotensin I-converting-enzyme-inhibitory and antimicrobial bioactive peptides, Int. J. Dairy Technol. 57 (2004) 173-188.

[22] Hernandez-Ledesma B., Recio I., Ramos M., Amigo L., Preparation of ovine and caprine $\beta$-lactoglobulin hydrolysates with ACE-inhibitory activity. Identification of active peptides from caprine $\beta$-lactoglobulin hydrolyzed with thermolysin, Int. Dairy J. 12 (2002) 805-812.

[23] Huang X.L., Catignani G.L., Swaisgood H.E., Comparison of the size and rate of formation of peptides released by limited proteolysis of $\beta$-lactoglobulins A and B with immobilized trypsin, J. Agric. Food Chem. 42 (1994) 1281-1284.

[24] Irvine D.M., Sheep's milk dairy products, in: Boylan W.J. (Ed.), Proc. North American Dairy Sheep Symposium, St Paul, USA 1989, pp. 135-146.

[25] Jost R., Monti J.C., Partial enzymatic hydrolysis of whey protein by trypsin, J. Dairy Sci. 60 (1977) 1387-1393.

[26] Kim Y.-K., Chung B.H., A novel angiotensin-I-converting enzyme inhibitory pep-

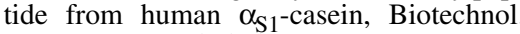
Lett. 21 (1999) 575-578.

[27] Kuehler C.A., Stine M.C., Effect of enzymatic hydrolysis on some functional properties of whey protein, J. Food Sci. 39 (1974) 379-382.

[28] Maruyama S., Suzuki H., A peptide inhibitor of angiotensin I converting enzyme in the tryptic hydrolysate of casein, Agric. Biol. Chem. 46 (1982) 1393-1394.
[29] Maruyama S., Nakagomi K., Tomizuka N., Suzuki H., Angiotensin-I-converting enzyme inhibitor derived from an enzymatic hydrolysate of casein. II. Isolation and bradykininpotentiating activity on the uterus and the ileum of rats, Agric. Biol. Chem. 49 (1985) 1405-1409.

[30] Maruyama S., Mitachi H., Tanaka H., Tomizuka N., Suzuki H., Studies on the active site and antihypertensive activity of angiotensin-Iconverting enzyme inhibitors derived from casein, Agric. Biol. Chem. 51 (1987) 15811586.

[31] Meisel H., Overview on milk proteinderived peptides, Int. Dairy J. 8 (1998) 363 373.

[32] Meisel H., Schlimme E., Inhibitors of angiotensin-converting-enzyme derived from bovine casein (casokinins), in: Brantl V., Teschemacher H. (Eds.), $\beta$-Casomorphins and Related Peptides: Recent Developments, Weinheim VCH, 1994, pp. 27-33.

[33] Minervini F., Algaron F., Rizzello C.G., Fox P.F., Monnet V., Gobbetti M., Angiotensin I-converting-enzyme-inhibitory and antibacterial peptides from Lactobacillus helveticus PR4 proteinase-hydrolyzed caseins of milk from six species, Appl. Environ. Microbiol. 69 (2003) 5297-5305.

[34] Mullally M.M., Meisel H., Fitzgerald R.J., Synthetic peptides corresponding to $\alpha$-lactalbumin and $\beta$-lactoglobulin sequences with angiotensin-I-converting enzyme inhibitory activity, Biol. Chem. Hoppe Seyler's 377 (1996) 259-260.

[35] Mullaly M.M., Meisel H., Fitzgerald R.J., Identification of a novel angiotensin-I-converting enzyme inhibitory peptide corresponding to a tryptic fragment of bovine $\beta$ lactoglobulin, FEBS Lett. 402 (1997) 99-101.

[36] Nakamura Y., Yamamoto M., Sakai K., Okubo A., Yamazaki S., Takano T., Purification and characterization of angiotensin-I-converting enzyme inhibitors from sour milk, J. Dairy Sci. 78 (1995) 777-783.

[37] Ozimek A., Fengler A., Szpacenko A., Wolfe F., Kinetics and efficiency of hydrolysis of native and denatured whey proteins by pancreatic enzymes in both batch and ultrafiltration membrane bioreactor systems, J. Dairy Sci. 76 (Suppl. 1) (1993) 99.

[38] Pihlanto A., Korhonen H., Bioactive peptides and proteins, in: Taylor S.L. (Ed.), Adv. Food Nutr. Res. vol. 47, Elsevier Academic Press, London, U.K., 2003, pp. 175-276.

[39] Pihlanto-Leppälä A., Rokka T., Korhonen H.J.T., Angiotensin-I-converting enzyme 
inhibitory peptides derived from bovine milk proteins, Int. Dairy J. 8 (1998) 325-331.

[40] Pihlanto-Leppälä A., Marnila P., Hubert L., Rokka T., Korhonen H., Karp M., The effect of alpha-lactalbumin and beta-lactoglobulin hydrolysates on the metabolic activity of Escherichia coli JM103, J. Appl. Microbiol. 87 (1999) 540-545.

[41] Pihlanto-Leppälä A., Koskinen P., Piilola K., Tupasela T., Korhonen H., AngiotensinI-converting enzyme inhibitory properties of whey protein digests: concentration and characterization of active peptides, J. Dairy Res. 67 (2000) 53-64.

[42] Schagger H., von Jagow G., Tricine-sodium dodecylsulfate-polyacrylamide gel electrophoresis for the separation of proteins in the range from 1 to $100 \mathrm{kDa}$, Anal. Biochem. 166 (1987) 368-379.

[43] Seppo L., Kerojoki O., Suomalainen T., Korpela R., The effect of a Lactobacillus helveticus LBK-16 $\mathrm{H}$ fermented milk on hypertension - a pilot study on human, Milchwissenschaft 57 (2002) 124-127.

[44] Seppo L., Jauhiainen T., Poussa T., Korpela R., A fermented milk high in bioactive peptides has a blood-pressure lowering effect in hypertensive subjects, Amer. J. Clin. Nutr. 77 (2003) 326-330.

[45] Sipola M., Finckenberg P., Santisteban J., Korpela R., Vapaatalo H., Nurminen M.-L., Long-term intake of milk peptides attenuates development of hypertension in spontaneously hypertensive rats, J. Physiol. Pharmacol. 52 (2001) 745-754.

[46] Sipola M., Finckenberg P., Korpela R., Vapaatalo H., Nurminen M.-L., Effect of long-term intake of milk products on blood pressure in hypertensive rats, J. Dairy Res. 69 (2002) 103-111.

[47] Takano T., Milk derived peptides and hypertension reduction, Int. Dairy J. 8 (1998) 375 381.

[48] Takano T., Anti-hypertensive activity of fermented dairy products containing biogenic peptides, Antonie van Leeuwenhoek 82 (2002) 333-340.

[49] van Beresteijn E.C.H., Peeters R.A., Kaper J., Meijer G.M.R., Robben A.J.P., Schmidt D.G., Molecular mass distribution, immunological properties and nutritive value of whey protein hydrolysates, J. Food Prot. 57 (1994) 619-625.

[50] van Willige R.W.G., Fitzegrald R.J., Tryptic and chymotryptic hydrolysis of $\beta$-lactoglobulin $\mathrm{A}, \mathrm{B}$ and $\mathrm{AB}$ at ambient and high pressure, Milchwissenschaft 50 (1995) 183-186.

[51] Yamamoto M., Akino A., Takano T., Antihypertensive effect of peptides derived from casein by an extracellular proteinase from Lactobacillus helveticus CP790, J. Dairy Sci. 77 (1994) 917-922. 